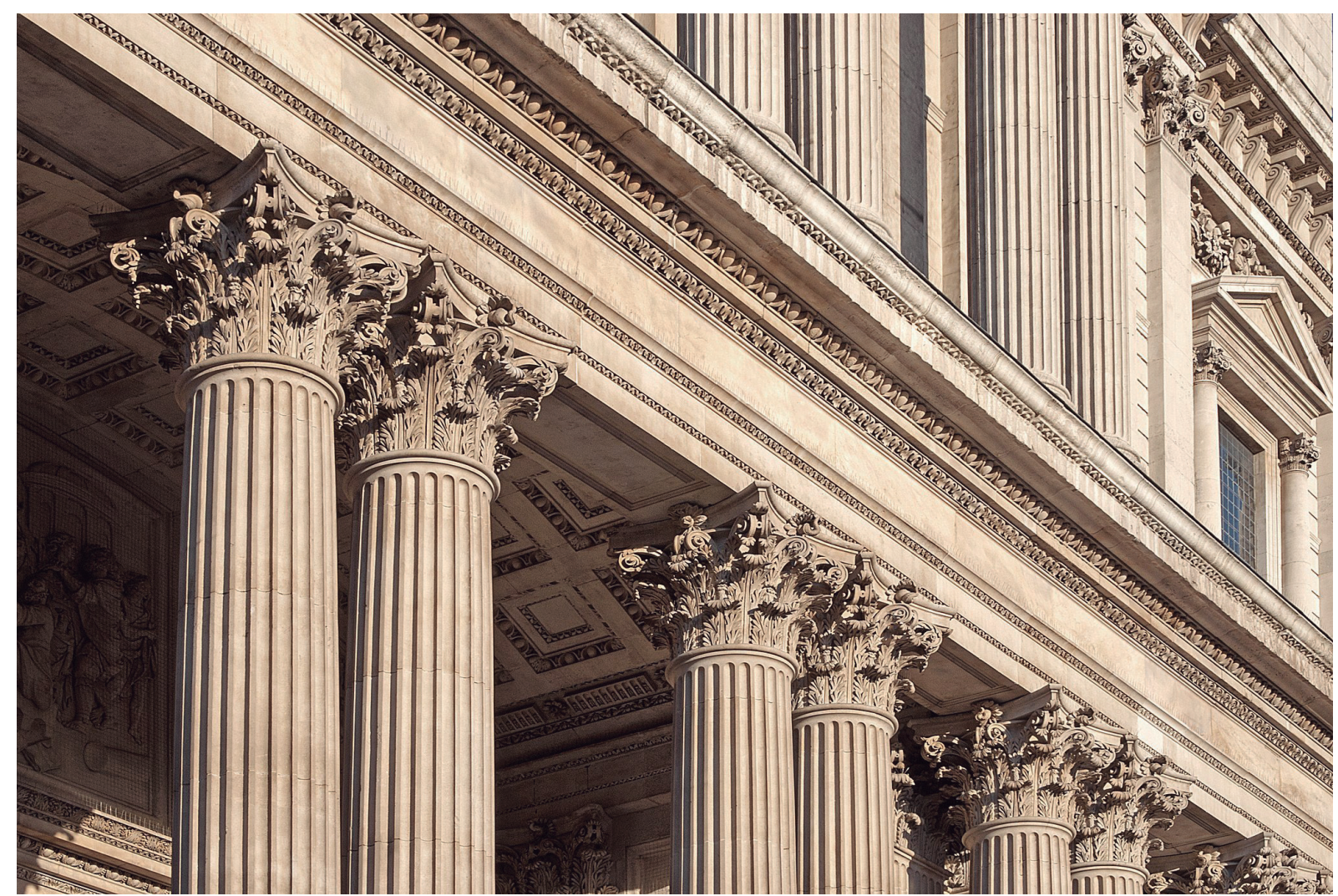




\section{Silent Partner: Design and Making in the Early Modern Architecture of Britain Christine Casey}

This article argues that, in early modern architecture in Britain, the role of making has been subordinated to that of design. It takes it cue from Gottfried Semper's image of the architect in antiquity as choragus or orchestrator of the many skills required to create a building, and demonstrates that knowledge of materials and craftsmanship informed the design process. It argues that the architect's role as orchestrator of craft production has been overlooked due to an overemphasis on conceptual design. The relationship of conceptual and intuitive approaches to building is explored, as is communication between architect and craftsmen through models and large-scale working drawings. The nonarchitectural concerns of plastic artists involved in architectural production are noted. Finally, historiographical tendencies toward stylistic and biographical attribution are shown to militate against a holistic view of design and craft in early modern architecture.

\section{KEYWORDS}

Craft, Early Modern Architecture, Tacit Knowledge, Collaboration

\section{PALABRAS CLAVE}

Artesanía, arquitectura moderna temprana, conocimiento tácito, atribución, colaboración

Buildings are conceived in the mind and translated into reality through the coordination of many skilled and unskilled hands. An overemphasis on design and the agency of individual architects has resulted in neglect of the reflective skill and tacit and embodied knowledge of the craftsman, and of the relationship between designer and craftsman in the architectural production of the early modern period. As Alina Payne has shown, "crafting" has almost been entirely written out of Renaissance architectural history. ${ }^{1}$ As part of a wider effort to write craftsmanship into the narrative of early modern architecture in Britain, this paper draws upon history and historiography to consider the interaction between

\begin{abstract}
Christine Casey
is a Professor in Architectural History at Trinity College Dublin and leads an Irish Research Council Advanced Laureate research project, CRAFTVALUE, which focuses on craftsmanship in eighteenthcentury architecture. From 2017 to 2019, she directed a project on the building industry in Victorian Dublin titled "Making Victorian Dublin." She has published widely on architecture and decoration, including the definitive reference work on Dublin city, Dublin (Yale University Press, 2005) and Making Magnificence: Architects, Stuccatori and the Eighteenth-century Interior (Yale University Press, 2017), and, with Patrick Wyse Jackson, The Museum Building of Trinity College Dublin: A Model of Victorian Craftsmanship (Dublin: Four Courts Press, 2019). In 2018, she was awarded the Alice Davis Hitchcock Medallion (2018) by the Society of Architectural Historians of Great Britain. A member of the Royal Irish Academy and an honorary member of the Royal Institute of the Architects of Ireland, she has served in national organizations for architectural heritage including the Castletown Foundation, The Alfred Beit Foundation, the Irish Georgian Society, and The Heritage Council. She has held numerous international research fellowships and has been elected Parnell Fellow, at Magdalene College, Cambridge, 2021-22. E-Mail: caseych@tcd.ie ORCID iD: 0000-0001-6316-1010
\end{abstract}

Fig. 01

Saint Paul's Cathedral, detail of portico, Laurence Mackman. Creative Commons Attribution-Share Alike 4.0 International license; https://commons. wikimedia.org/wiki/File:St_Pauls_ Cathedral_Front_Elevation_Capitals_ Detail.jpg 
architect and craftsman in the long eighteenth century and the barriers to understanding this relationship. ${ }^{2}$ It counters traditional biographical and design-driven models of architectural history that assume an overwhelming impact of design in building activity, and instead reflects the position of craft theorists, such as David Pye, who argue that workmanship is responsible for "a great part of the quality of our environment." It takes its ultimate cue from Gottfried Semper's admittedly partisan image of the architect in antiquity as choragus or orchestrator of the many skills required to create a building: "The architect was the choragus -he led them- his name even says it. He was chosen from among the artists less for his sweeping mastery of all the arts than for his special gift of assessing the situation, allocating the resources, and for having a sharp eye for disposition and economy of means. He impartially supervised the whole, not yet enfeebled by theoretical matters, and found willing assistance from all the artists who did not yet feel as if they were stooping to the level of decorative painters and stucco workers when serving under the architect."4

Retrieving the voice of the early modern craft practitioner is a challenging task as so much of the surviving evidence comes from the writings or records of patrons and architects. To prise open the elusive space between design and making, we must cast the net wide and capture fugitive instances of interaction between material, technology, and design. While construction history has already done much in this regard, it has not sufficiently addressed the non-structural, surface treatments of early modern buildings, which tend to fall between the disciplines of art history and architectural history, being considered too modest for the former and too ornamental for the latter. Yet, as Sir William Chambers asserted in the eighteenth century, architecture "is indebted to sculpture for a great part of its magnificence." This essay therefore assembles a picture of interaction between early modern architects and craftsmen in Britain from a broad range of primary and secondary material, and in a thematic rather than strictly chronological fashion. Its themes include the engagement of architects with the stone industry, the role of the architect in the appraisal and measuring of workmanship, the divergence of language and methods in the practices of design and craft, which tended to demean the latter, the interface or means of communication between the architect and artisan and its potential for misunderstanding, and the tendency of commentaries to overlook building professionals and attribute all buildings of pretension to known architects. Sir Christopher Wren provides a basis for this discussion because of the survival of rich documentation for Saint Paul's and the churches of the City of London, the extensive testimony of his contemporaries, and the efforts of scholars in analyzing the wider world of architectural labor at the cathedral. Yet, even here, there remain significant gaps, such as the absence of published scholarship on the stone carvings and composition of the orders in Wren's buildings. However, the cathedral workshop does provide a basis for understanding widespread work practices in eighteenth-century British architecture, because it was there that benchmark practice was established under Wren's supervision and through a succession of clerks of works, draftsmen, and craft practitioners, including Nicholas Hawksmoor, and dynasties of master masons from Oxfordshire and the Isle of Portland in Dorset. Masons and carvers, skilled in the handling and sculpting of Portland stone, were much in demand throughout the eighteenth century, since this soft white limestone was the material of choice for classical architecture across Britain and Ireland. 
While design and drawing might be taught through book, instrument, and rules, translating design into stone, bricks, and mortar was learned primarily through trial and error in the experience of the building process, and was informed by the knowledge and skills of quarrymen, timber merchants, building contractors, and craftsmen. Knowledge of the properties of dimension stone was vital for the achievement of monumental architecture. Wren told Roger North that material restrictions prevented the employment of a single giant order in St Paul's portico (fig. 01). This partially dictated the use of paired, superimposed orders with smaller entablatures, which would not crush the obligatory multi-drum columns, and relieving arches in the entablatures, which would secure the intercolumniations. ${ }^{6}$ While calculation played a significant role in Wren's decision, the wisdom and advice of quarrymen and masons should not be underestimated. On November 18, 1676, as the designs for Saint Paul's were evolving, the surveyor Robert Hooke dined with Wren, after which a stone merchant spoke with them about Portland stone. ${ }^{7}$ Earlier, in 1672, Hooke received a "Mr Andrewes" to discuss Kentish quarries, and throughout the decade refers to the direct examination, delivery, and at times rejection of stone or marble. ${ }^{8}$ Wren arrived at the profile of the dome in collaboration with his masons and ironsmiths: both he and Hawksmoor relied upon masons from Burford in Oxfordshire to interpret their designs and to act almost in the capacity of site architects. "Apply yourself to old Mr Strong," wrote Nicholas Hawksmoor in 1705 to Henry Joynes, the Clerk of Works at Blenheim, of Edward Strong, the principal mason there and at Saint Paul's Cathedral, "he will assist you," "if you find anything di[u]bious pray call Mr Strong to your aid." ${ }^{10}$ Decades later, Sir William Chambers likewise placed his faith in the knowledge of stonemasons. Writing to his clerk of works at Woburn Abbey about the procurement of stone for the new bridge, Chambers feared that he would not have the time to join the master mason at the quarry: "If I possibly can I will meet Cowley at Astridge but I am not certain that my time will permit me. Neither is it material as he understands the Nature of the stone better than I do therefore all that I have to recommend to him is Accuracy in his Dimensions."11 The give-and-take of these effective working relationships was aided by direct communication, as the architect William Winde stated about the plasterer Edward Goudge in 1684: "For it is almost impossible ... that I should be either able to judge of the draughts or of his prices, except he had beene (sic) with me or I with him; there being some things in the draught that I would have altered; which I am unwilling to do until I speake with him my selfe (sic)...."'2 Correspondence was more often the normal channel for instruction and clarification, as shown by a somewhat tongue-in-cheek letter from the master mason Hugh Darley in Dublin in 1755 to the architect Henry Keene in London, seeking advice on the costing and measuring of carved stone festoons and entablature enrichments at Trinity College (fig. 02): "All these particulars I must beg you will answer in the most explicit manner in your power for you know that we Irishmen are somewhat thick-headed and Great Care must be taken in the Value or rates of the respective parts because as I have made no agreement with the Carver, we are resolved to abide by your Determination."13

Then, as now, sustained collaborations between architects and craftsmen rested upon assurance of quality in materials and workmanship. An essential part of the architect's task was measuring or appraisal, without which payments for workmanship could not be made. This was a task that embraced all aspects of building, from structural 


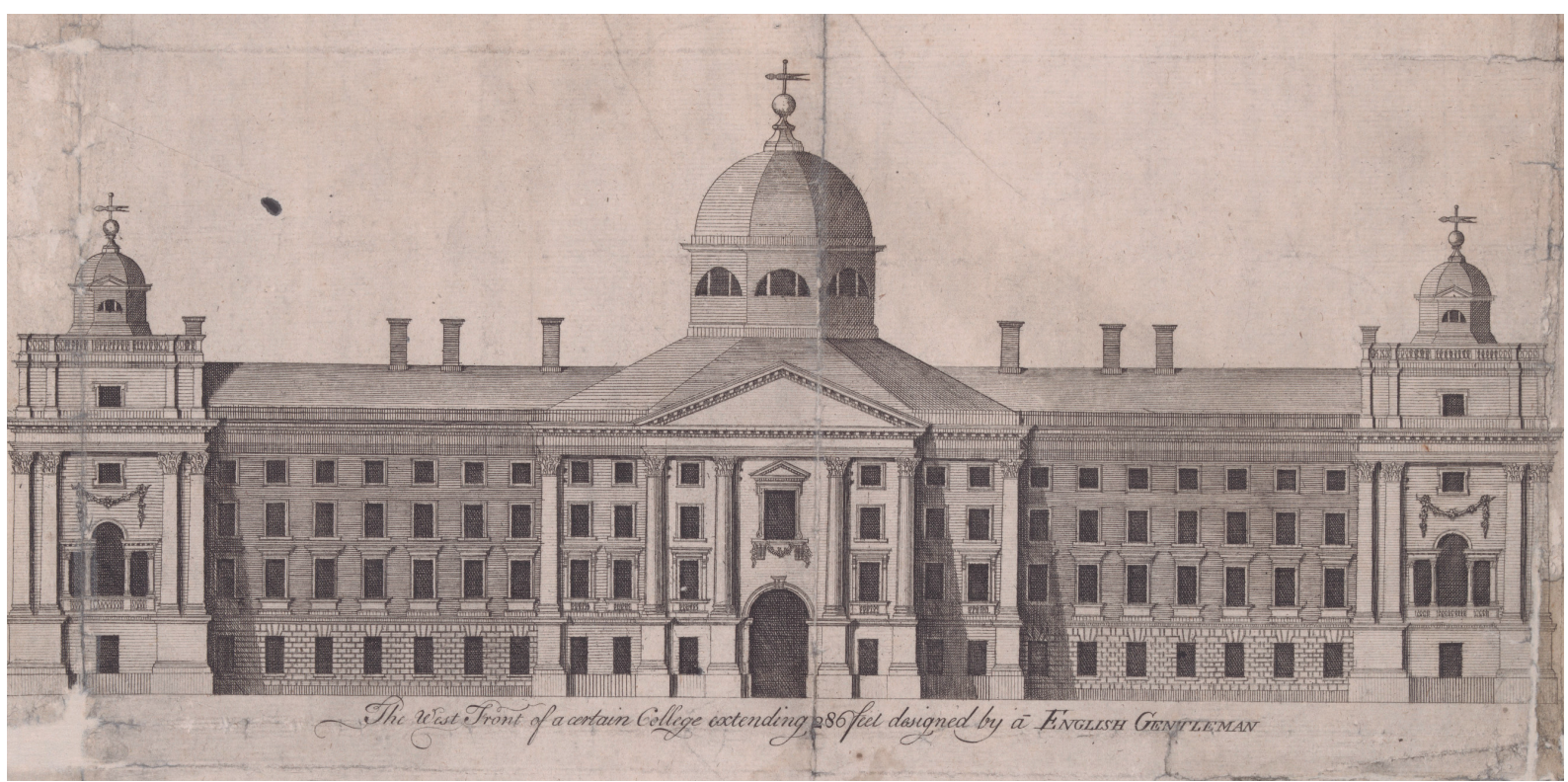

02

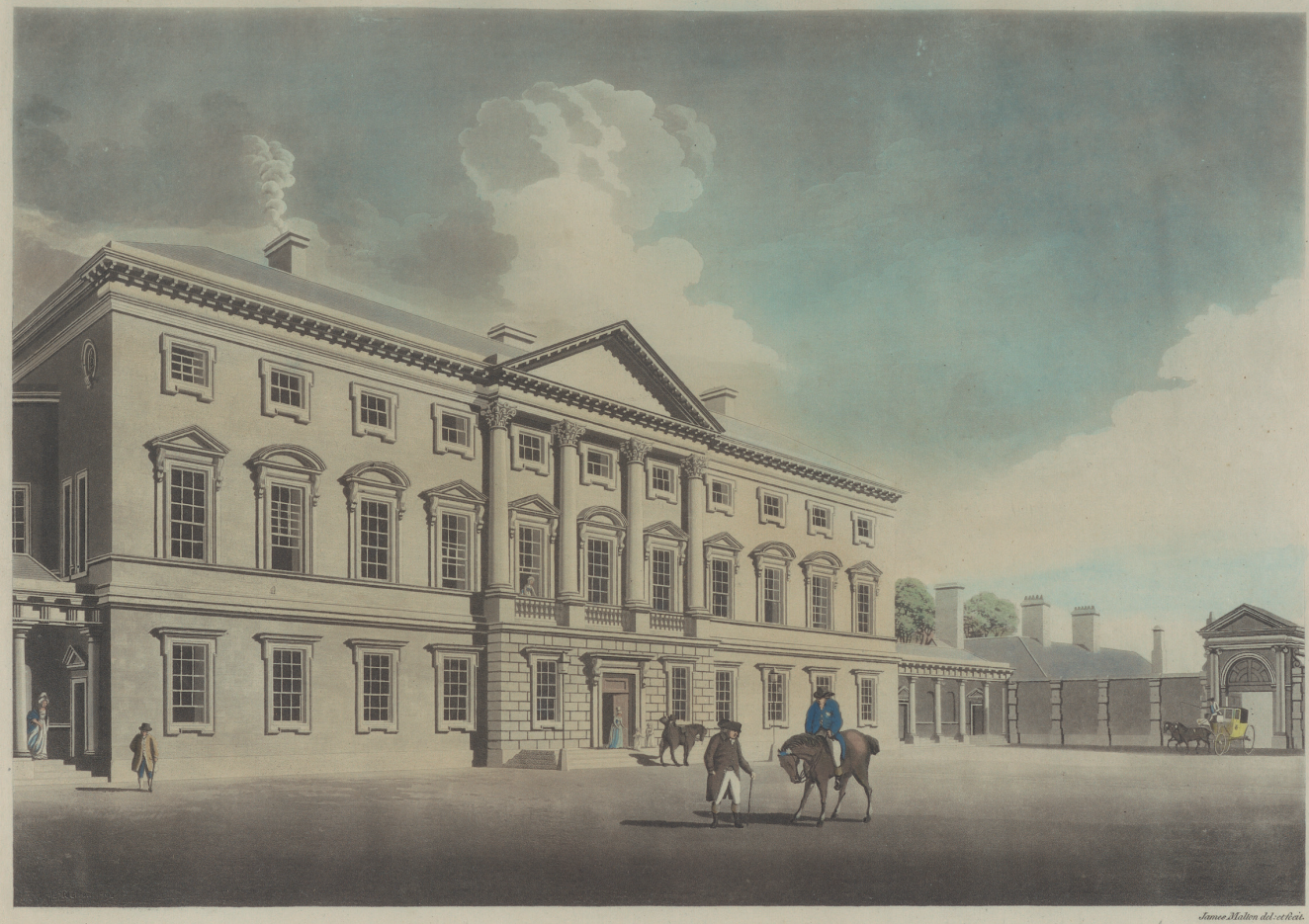

ZLETNSTER HOUSE, DUBLIN.

taminsustatis 
brickwork to the carvings of marble chimneypieces. Richard Castle, the leading architect in Ireland in the 1730s and 1740s, placed great value on workmanship, assuring a client that, "a skill full bricklayer" equipped with a suitably long slab of stone could manage to span the floor joists to seat a hearth with no true bearing. ${ }^{14} \mathrm{~A}$ brief, posthumous biography of Castle proclaimed him to be "so clear in his directions to workmen, that the most ignorant could not err.... When the effect of his works was not such as he liked, he frequently pulled them down, and whenever he came to inspect them, he required the attendance of all the artificers, who followed him in a long train"15 (fig. 03). James Gibbs is likewise recorded as having unsatisfactory work pulled down, while he conversely expressed praise and "good liking" for the productions of preferred craftsmen. ${ }^{16}$ Thus, an essential, if largely unexpressed aspect of the architect's role was judging and appraising skilled craftsmanship, in which considerations regarding quantity, quality, and value were taken into account. At Chatsworth, in assessing the carvings, Wren deducted "little in such things as require the hand of a Master to perform."17 The work of the carver Grinling Gibbons appears to have met with almost universal satisfaction, or so he informed the disgruntled Duke of Chandos in 1718, who took him at his word and agreed to pay in full, even though he considered the workmanship to be of insufficient quality for the price. ${ }^{18}$ Only when payment was withheld and litigation ensued were the subtleties of appraisal articulated, as seen in a celebrated case in the 1680 s between the Carthusian monks of San Martino in Naples and their architect Cosimo Fanzago. ${ }^{19}$ In the monastic chapel, now famed for its virtuoso marble inlay, the assessment of the expert measurers, rendered in precise Vitruvian vocabulary, noted fluctuations in the quality of execution from worthless to good quality based on criteria of "greater manufacture" and difficulty in carving. ${ }^{20}$ Sourcing and retaining high quality craftsmanship were further aspects of the architect's role, often against the will of the client, as voiced by the architect John Adam, in answer to his patron John Paterson of Hopetoun, who was angry about the charges of his joiner: "There is no doubt the prices seem high," wrote Adam "but there is no doing a thing in an extraordinary manner without a price equal to the pains."21

Yet, while craft was essential to high-quality building, it found no place in the wider value systems of the period. Though captured by the eye and the measuring cord of the appraiser, complexity and speed of tool-handling skills, intuitive understanding of materials and tacit proportional judgment resisted theorization and contributed to a persistent view of the craftsman as an illiterate and innumerate practitioner necessarily reliant upon the higher quantifiable skills of the architect and the surveyor. Thomas Bedwell, the inventor of a carpenter's rule in the late-sixteenth century, proclaimed it "enough for them to know that it is so, although they are altogether ignorant of why it is so."2 "How simple are those men that work daily and know not what a symmetry is," wrote Robert Stickells, a contemporary, upwardly-mobile master mason, "no not so much as to double his two foot rule that he carrieth up and down in his hand (sic)."23 This underestimation of manual skills was linked to the means with which they were remunerated. The work of sculptors, master masons, plasterers, and joiners, however accomplished, was paid by measure, in contrast to the architect's payment by fee or percentage. The gap between design and making was amplified by divergences in drawing and building practice. The diverse proportional instructions of architectural treatises for the diminution and
Fig. 02

West front of Trinity College Dublin by John Aheron, showing the façade with an unbuilt dome and cupolas. Reproduced with permission of the Board of Trinity College Dublin, the University of Dublin.

Fig. $\mathrm{O3}$

Leinster House, formerly Kildare House, Dublin, built to the design of Richard Castle from 1745, engraved by James Malton. Reproduced courtesy of the Irish Architectural Archive. 
Fig. 04

Page from a mid-eighteenth century annotated translation of Vitruvius, $D e$ architectura, libri decem by the Dublin carpenter-architect Michael Wills. Courtesy of the Chester Beatty Library, Dublin.

Fig. 05

"Les moulures," Augustin Charles d'Aviler, Cours d'architecture, Paris, Jean Mariette, 1738. https://archive.org/details/ coursdarchitectuOOavil/page/7/mode/1up

Fig. 06

The Radcliffe Camera, Bodleian Library, Oxford University by Roman Kirillov This file is licensed under the Creative Commons Attribution-Share Alike 3.0 Unported license; https://commons. wikimedia.org/wiki/File:Bodleian_ Library.jpg entasis of columns is a case in point, and it seems that Palladio's pragmatic rule of thumb for the achievement of entasis was widely used by craftsmen, although it, in the absence of precise measurements, evidently left much room for variation. Michael Wills, a Dublin carpenter-architect and early translator of Vitruvius, claimed that, in the mid-eighteenth century, entasis of the column was "formed by the bending of a lath, so as the middle may be no thicker than the bottom, by confining the lath at one third of the height" ${ }^{\prime 24}$ (fig. 04). This is corroborated by John Evelyn, who considered the practice so common that he deigned to describe it as follows: "The manner of Operation of applying a thin flat flexible Rule, of the length of the whole Column, divided into three equal parts, beginning at the Perpendicular of the lowest is so well known, that I need say nothing more of it, than that there is hardly any sensible swelling to be perceived in the best examples, and therefore to be sparingly us'd (sic), and with Discretion, if at all." ${ }^{25}$ The language or terminology used in intellectual and manual domains also differed. Augustin Charles d'Aviler's Cours d'architecture demonstrates the divergence in the languages of architectural treatises from common usage: the astragal was known to "ouvriers" as a "baguette" and the upper torus as a "boudin" or form of black pudding ${ }^{26}$ (fig. 05). This early modern building site vernacular is also captured in Hugh Darley's letter cited above. Seeking the per foot cost of an enriched astragal molding of the entablature at Trinity
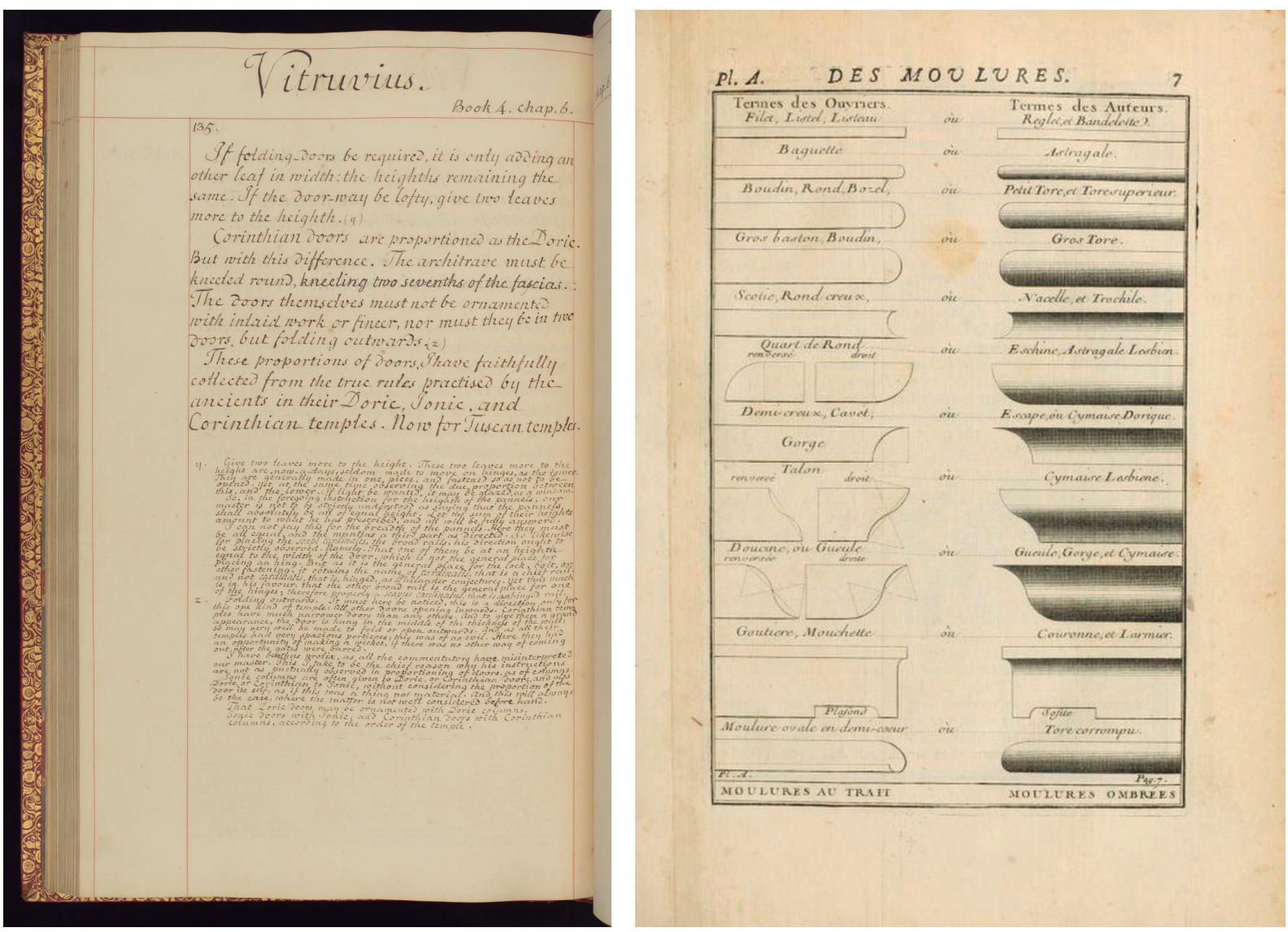


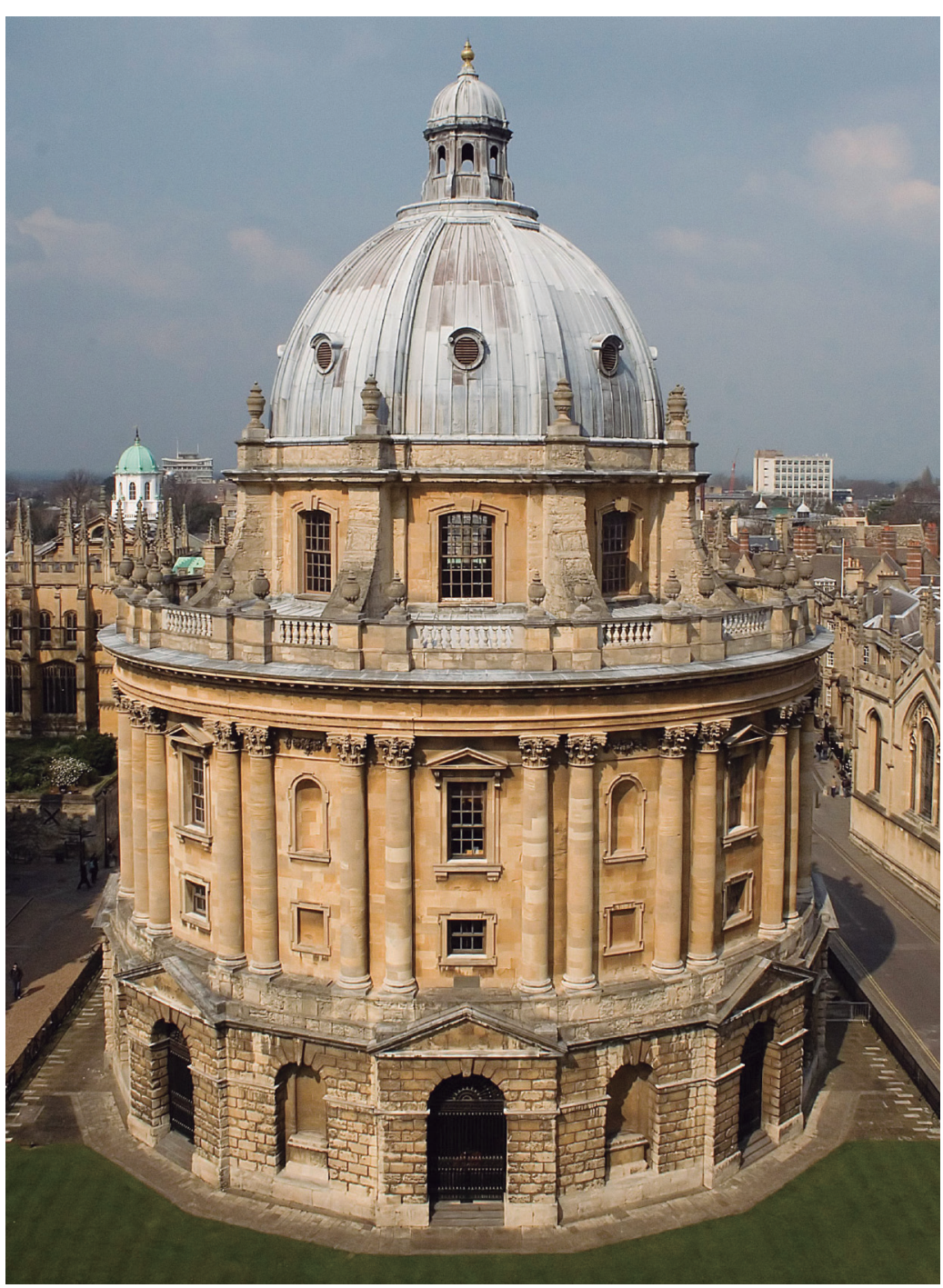

06

College, Dublin, Darley described the bead-and-reel molding as "carved with what our Carvers call bends and bubbles." ${ }^{27}$ At the Radcliffe Camera in Oxford, the masons likewise referred to runs and enrichments of "bubbles" and "split" tongues, a descriptive terminology that points to the essentially visual nature of the transmission of the ornamental (fig. 06). ${ }^{28}$

Besides extensive onsite discussions and letters of instruction, drawings and models were the principal means of communication between architect and craftsmen. Despite his trust in individual craftsmen, for whom he relaxed his customary control, Wren sought to direct, in so far as possible, all aspects of execution down to the detail of architraves and cornices. Writing to the master of Trinity College, Cambridge, he offered to take a further pains "to give all the mouldings in great" "more proper for the use of the workmen," proclaiming architects "as great pedants as Critics or Heralds," and promising to return to the original designs, for in the hands of the workman they would soon be so defaced that they would not serve to bring the work to a conclusion. ${ }^{29}$ 


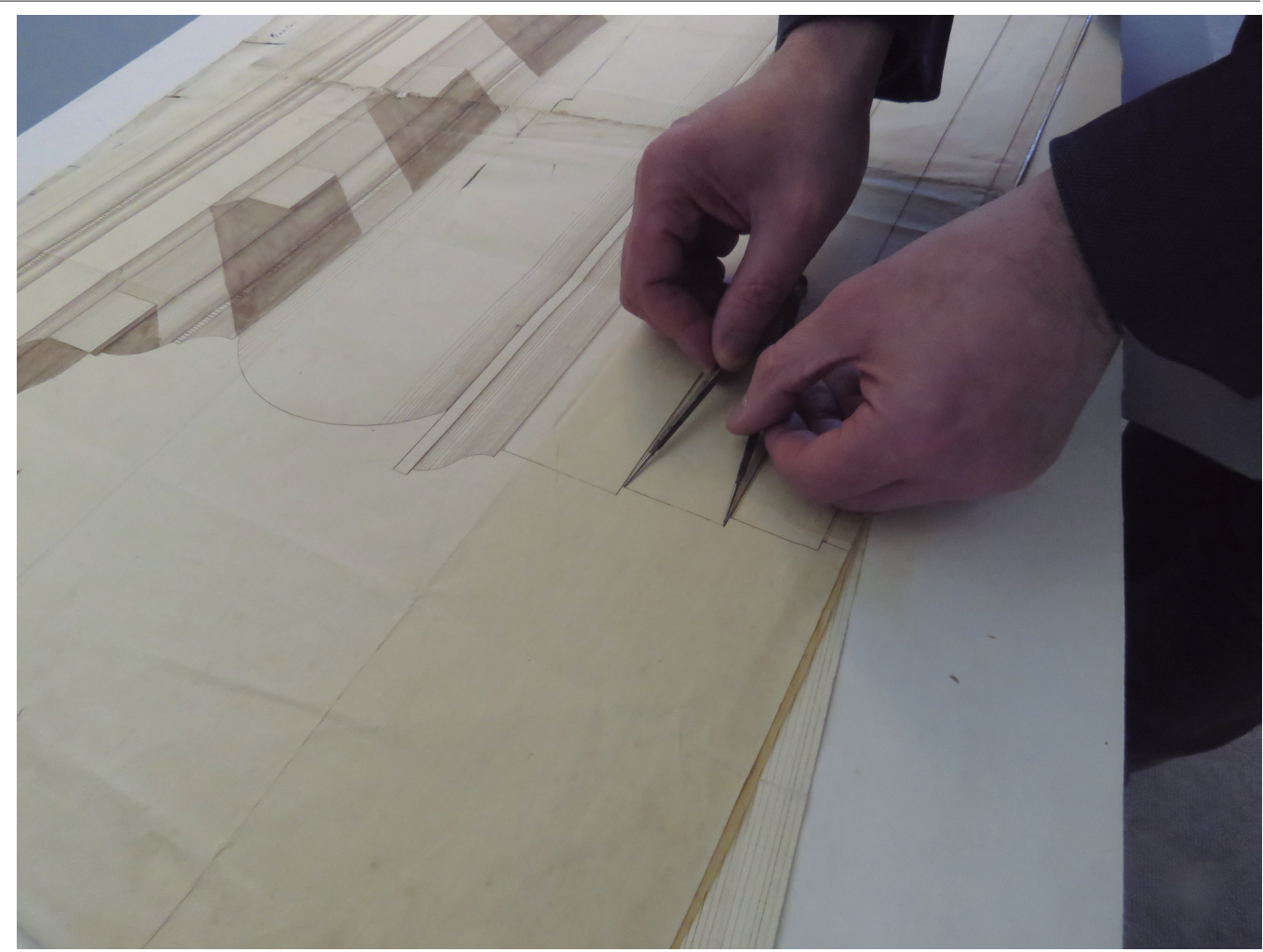

07

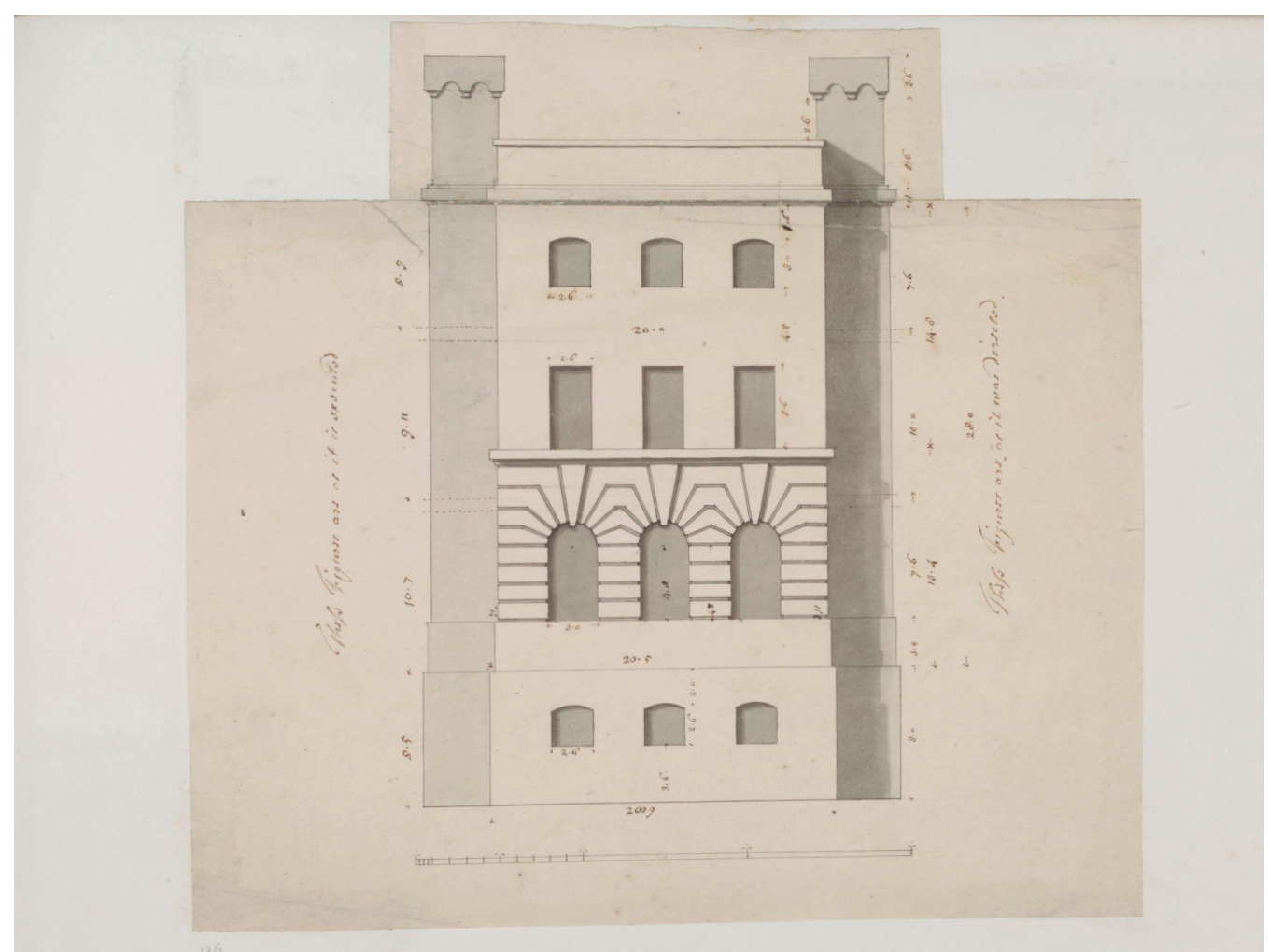


In the late seventeenth and early eighteenth century, models were still considered the optimum means for communicating a design to craftsmen. Roger North considered it difficult to instruct workmen "from a draught in plano," while William Cooley, writing to the Earl of Egmont in 1748 , begged "to entreat your Lordship to make a moddle (sic) and that by no less than half an inch to a foot," as "it is next to impossible to get so great a number of different tradesmen to finish each his part to perfection without a moddle which as it may be taken to pieces each man may view it with pleasure." ${ }^{30}$ Few models survive and even fewer of the largescale drawings, which were the next best means of communication. Rare surviving working drawings from the 1740s for the entablature and balustrade (fig.07) of Carton House in County Kildare show the time invested by Richard Castle in careful communication with his stonemasons. The scale represented is one inch to three-eights of an inch and corresponds closely to the completed building. ${ }^{31}$ Their survival is puzzling and may perhaps relate to Castle's sudden and untimely death in his lodgings at Carton House while writing a no longer extant letter of instruction to a carpenter at his client's city residence.

Yet, despite all the letters of instruction, on-site directions, explanatory models, and scale drawings, much was still lost in the translation from design to execution. A drawing by Vanbrugh's office for the White Tower at Greenwich is inscribed with two slightly differing sets of dimensions, on one side of the elevation, "[t] these figures are as executed," and on the other, "[t]hese figures are as it was directed" (fig. 08). ${ }^{32}$ Many of the Vanbrugh drawings have no scale bar, but instead merely a simple written scale of however many feet to an inch. Care was invested instead in writing the dimensions. On an elevation for the episcopal palace at Cashel Palace in County Tipperary, Vanbrugh's cousin Edward Lovett Pearce specified that each quoin should be fourteen inches high and the chamfer of three inches, ${ }^{33}$ while rare drawings from circa 1740 for the composition of the stonework in the façade of Dromoland Castle in County Clare provide a numerical key to the dimensions of the ashlar, quoins, and voussoirs. ${ }^{34}$ Reliance upon dimensions rather than scale reflects a distrust of graphical convention and a faith in numbers that has persisted into the modern age. "Do not scale drawing, work to figured dimensions" is a long-standing disclaimer that reflects the problems of working to scale when an ink line might represent several inches. Design by correspondence in eighteenth-century Britain increased the potential for misunderstandings of scale, as the correspondence of Sir William Chambers clearly shows. In a letter of 1770 , Chambers reprimanded his builder at Milton Abbey, Stephen Carpenter of Blandford, "I am almost sure my cellar plan was rightly figured and therefore it must be owing to some mistake of yours, ... You seem to talk with very great indifference about the exactness of Your work. You tell me that upon the whole you do know but all your dimensions agree, excepting that you have lost three feet in one of the fronts. From a Master Builder other language is expected." ${ }^{35}$ At the Radcliffe Camera, the drawings provided by James Gibbs to the stuccatore Giuseppe Artari gave an incorrect ceiling height, and Artari was obliged to significantly alter his work in design and execution because it was nearer the eye and consequently needed to be more refined or "gentile." ${ }^{36}$ Artari's additional efforts were explained in his bill and accepted by Gibbs, who agreed that Artari "has really done more than he agreed for...."37

\section{Fig. 07}

Drawing by Richard Castle for the cornice at Carton House, County Kildare ca. 1740. Courtesy of the Irish Architectural Archive.

Fig. 08

"Side elevation of a building, New White Tower, Greenwich." Sir John Vanbrugh, Vanbrugh Album, E.2121: 136-1992.

(c) Victoria and Albert Museum, London. 
Fig. 09

John Michael Rysbrack, Design for a chimneypiece, E476.1946. () Victoria and Albert Museum, London.

Fig. 10

St Paul's Cathedral, London. Source: Historic England Archive.

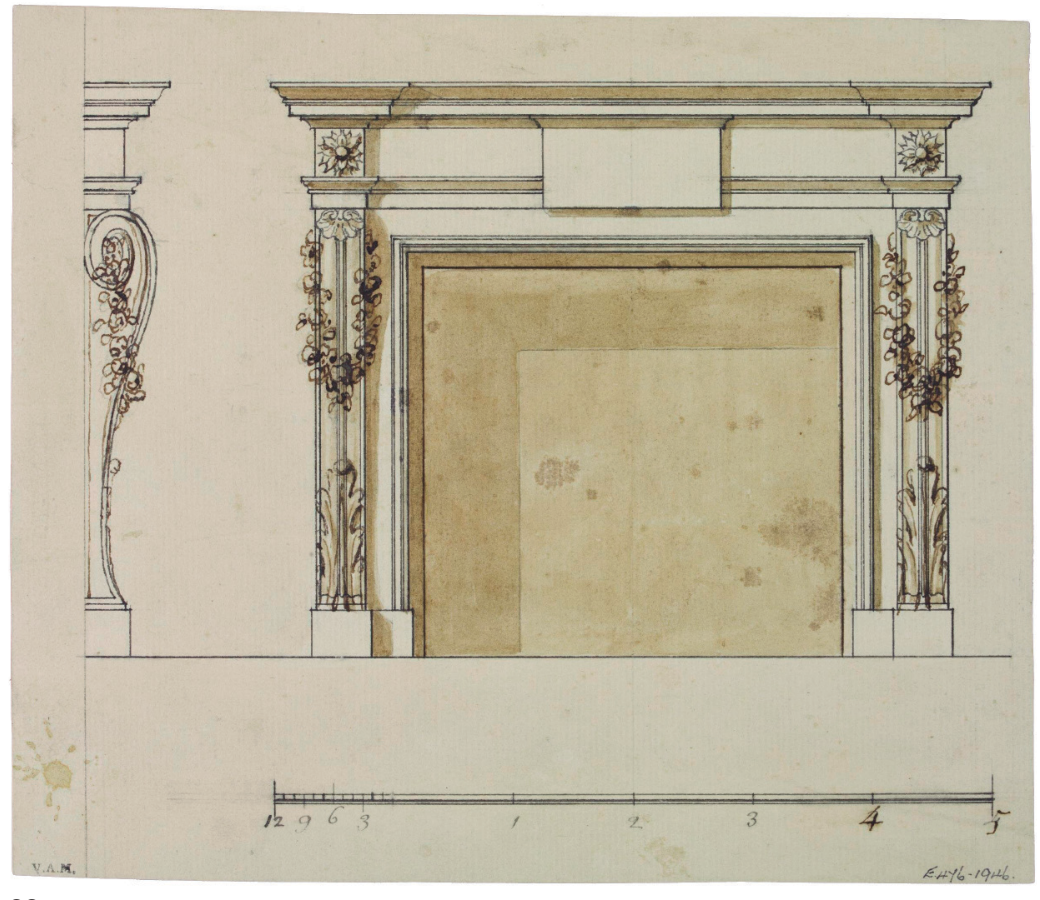

09




The technical and artistic skill of the craftsman was thus of central importance in achieving decorative surfaces. Wren, Gibbs, and Castle were effective designers of ornament and produced drawings for competent classical detailing. Surviving designs in wood and stone by sculptors and by stuccatori or modelers of decorative plasterwork differ from those of the architects in significant ways, being generally more spirited and impressionistic, with a figurative and decorative verve not found in the controlled manner of architectural designs (fig. 09). While architects generally sought to draw carved and modeled imagery within their compositional norms, artists were habitually drawn to plasticity, the manipulation of surface lighting, and a haptic exploitation of materials. "If I handed you a chisel and asked you to carve, you'd see what I mean," wrote David Esterly in his quest to recreate the lost work of Grinling Gibbons. "Trying to make an accurate slice in a varying terrain, you'd realize that gathering information about that matrix of grain and rays and pores is as much the blade's job as cutting it is. You can't rely on your eyes, which tell you little about the local structure of the wood. Besides, the cutting occurs out of sight, below the surface. What your muscles need is immediate tangible feedback from the moving blade." ${ }^{38}$ Wren disapproved of the young Gibbons's efforts at biblical bas-relief, but whole-heartedly embraced his virtuosity following a pragmatic conversion to decorative sculpture. And while Gibbons's brilliance in torturing wood to its plastic limits has attracted art historical scholarship, historians of architecture and sculpture have largely neglected to address architectural carving.

A further aspect of architectural history that illuminates the imbalanced record of design and making in early modern architecture is the field of attribution. Too many domestic buildings of the long eighteenth century are attributed to too few architects. In Ireland, Richard Castle is the likeliest suspect, and most houses of the 1730s and 1740s without archival records are ascribed to him, while contemporary craftsmen-architects such as Michael Wills fall beneath notice. Likewise, in eighteenthcentury England and Scotland, what was surely the extensive practice of provincial builder-architects receives scant attention, while attributions to known architects abound. "As with Inigo Jones, as with Wren, as with Robert Adam, the temptation is strong to father any building of quality with the right date on to the favoured name. This is a dangerous procedure because it can all too easily degenerate into a circular argument."39 "What do we mean by a Wren church?," asks Andrew Saint. "Architecture is a highly organised collaborative business. The designer never stands alone... In the end 'by' in architecture does not mean design. What it means is authority, decisiveness, and control. Wren is the architect of the Wren churches not because he designs everything but because he is in control." ${ }^{.00}$ As we have seen, Wren depended upon skilled quarrymen and craftsmen to achieve his buildings. As James Campbell has so eloquently argued, the famed and oft-quoted motto from the monument to Wren, erected in Saint Paul's cathedral by his son: "LECTOR, SI MONUMENTUM REQUIRIS, CIRCUMSPICE" (Reader, if you seek a monument, look around you) could be applied not just to Wren, but to all those involved in the construction of this most remarkable building" (fig. 10). ${ }^{41} \mathrm{RA}$ 
01. PAYNE, Alina, "Materiality, Crafting and Scale in Renaissance Architecture," in Oxford Art Journal, 2009, 32, 3, pp. 367-86, esp. p. 385.

02. This essay stems from a research project titled CRAFTVALUE (www. craftvalue.org) which explores the relationship of craftsmanship and architecture in the long eighteenth century in Britain and a related UK-IR network project entitled 3D CRAFT jointly led by the National Trust (UK) and Trinity College Dublin https://gtr.ukri.org/ projects?ref=AH\%2FVOO2333\%2F1/ https://craftvalue.org/3d-craft/, which explores digital methods of analyzing craft practice in eighteenth-century architecture (all URLs accessed in June 2021).

03. PYE, David, The Nature and Art of Workmanship, Cambridge University Press, Cambridge, 1968, p. 1.

04. SEMPER, Gottfried, "Preliminary remarks on polychrome architecture and sculpture in antiquity" (1834), in The Four Elements of Architecture and Other Writings, trans. Harry Francis Mallgrave and Wolfgang Hermann, Cambridge University Press, Cambridge / New York, 1989, p. 52.

05. CHAMBERS, William, $A$ Treatise on the Decorative Part of Civil Architecture, London, 1825, vol. Il, p. 375, cited in William Laffan and Kevin V. Mulligan, "Drawings for the Attic Statuary of the Casino at Marino," in Irish Architectural and Decorative Studies, 2013, xvi, pp. 145-60, esp. p. 151.

06. COLVIN, Howard, and NEWMAN, John, Of Building: Roger North's Writings on Architecture, Oxford University Press, Oxford, 1981, p. xvii.

07. ROBINSON, Henry W., and ADAMS, Walter (eds.), The Diary of Robert Hooke M.A., M.D., F.R.S. 1672-1680, Taylor \& Francis, London, 1935, p. 257.

08. Ibid., pp. 17, 130-34, 143, 152, 175, 182-84, 188, 213, 228, 241, 246, 313, and 329.

09. HIGGOT, Gordon, "Geometry and Structure in the Dome of Saint Paul's," in Anthony Gerbino and Stephen Johnston, Compass and Rule: Architecture as Mathematical Practice in England, 15001750 , Yale University Press, New Haven and London, 2009, p. 164.
10. MOBUS, Melody A.C., "The Burford Masons and the Changing World of Building Practice in England 1630-1730," PhD dissertation, The Open University, 2012, p. 250; http://oro.open. ac.uk/54509/1/578641.pdf; Kerry Downes, Hawskmoor, A. Zwemmer, London, 1979, p. 237.

\section{British Library ADD MS 41133, f.19 recto and verso.}

12. COLVIN, Howard, "Letters and Papers Relating to the Rebuilding of Combe Abbey, Warwickshire," in Walpole Society, 1984, 50, p. 284.

13. Trinity College Dublin, Department of Manuscripts MUN P/2/98.

14. V\&A, Department of Prints and Drawings, Vanbrugh Album, "Remarks upon the Plans here inclosed," E21247-1992.

15. ANON, Anthologia Hibernica, Dublin, October 1793, pp. 242-43.

16. FRIEDMAN, Terry, James Gibbs, Yale University Press, New Haven and London, 1984, p. 27; GIBBS, James, $A$ Book of Architecture: Containing Designs of Buildings and Ornaments, London, 1728, pp. $\mathrm{v}$, vii, ix, and xxii-xxiv.

17. GREEN, David, Grinling Gibbons: His Work as Carver and Statuary, Country Life, London, 1964, p. 120.

18. Ibid., p. 169.

19. NAPOLI, John Nicholas, "The Art of the Appraisal: Measuring, Evaluating and Valuing Architecture in Early Modern Europe," in Memoirs of the American Academy in Rome, 2009, liv, pp. 201-44.

20. Ibid., p. 236

21. ROWAN, Alistair, "The Building of Hopetoun," in Architectural History, 1984, 27, p. 196.

22. JOHNSTON, Stephen, "Making Mathematical Practice: Gentlemen, Practitioners and Artisans in Elizabethan England," $\mathrm{PhD}$ dissertation, Cambridge University, 1994, Chapter 4, pp. 212-14; http://www.mhs.ox.ac.uk/staff/saj/thesis/

23. Ibid.
24. Chester Beatty Library, Dublin, MS W192, ff. 9010, Michael Wills's annotated manuscript translation of Vitruvius's $D e$ Architectura, completed ca.1770. See Christine Casey, "De Architectura: An Irish Eighteenth-century Gloss," in Architectural History 37 (1994), pp. 80-95.

25. EVELYN, John, An Account of Architects and Architecture, London, 1706, p. 20.

26. D'AVILER, Charles Auguste, Cours d'Architecture, Jean Mariette, Paris, 1738 , p. 7; https://archive.org/details/ coursdarchitectuOOavil/page/6/mode/2up

27. Letter from Hugh Darley, February 15, 1755, Trinity College Dublin, Department of Manuscripts MUN P/2/98.

28. GILLAM, S.G., The Building Accounts of the Radcliffe Camera,Oxford Historical Society, Oxford, 1958, p. 53.

29. The Fifth Volume of the Wren Society: Original Wren Drawings from All Souls, Hans Sloane, and Sir John Soane's Collections, Wren Society, Oxford, 1928, pp. 32-33.

30. COLVIN, Howard, and NEWMAN, John (eds.), Of Building: Roger North's Writings, Clarendon Press, Oxford, 1981, p. 34.

National Library of Ireland, Egmont papers P4916, Letter from William Cooley to Lord Egmont, Lohort Castle, County Cork, August 12, 1748.

31. Irish Architectural Archive, Drawings for Carton House, County Kildare, Office of Richard Castle, 2/11/13, elevation of a cornice for the main block.

32. V\&A, Department of Prints and Drawings, Vanbrugh Album, Side Elevation for the New White Tower, Greenwich E2124.136-1992.

33. V\&A, Department of Prints and Drawings, Vanbrugh Album, Edward Lovett Pearce, Design for the Elevation of Cashel Palace, Co. Tipperary c. 1731, E2124.1721992.

34. Irish Architectural Archive, private collection, xerox copies.

35. British Library AD MS 41133 f. 45, Chambers to Carpenter. 


\section{Bibliography}

36. Badminton Archives, FMJ/4/1/1, January 2, 1744/5, Giuseppe Artari to the 3rd Duke of Beaufort.

37. Badminton Archives, ibid., March 10, $1737 / 8$, James Gibbs to the 3rd Duke of Beaufort.

38. ESTERLEY, David, The Lost Carving: A Journey to the Heart of Making, "Prelude," Duckworth Overlook, London, 2014, 2nd ed., p. 189

39. CRAIG, Maurice, "The Quest for Sir Edward Lovett Pearce," in Irish Arts Review, 1996, 12, p. 33.

40. SAINT, Andrew, "The conundrum of "by,"' in Malcolm Airs and William Whyte (eds.), Architectural History after Colvin: the Society of Architectural Historians of Great Britain Symposium 2011,Shaun Tyas, Donington, 2013, pp. 1-17.

41. CAMPBELL, James W.P., Building Saint Paul's, Thames and Hudson, London, 2007) p. 169.
- CAMPBELL, James W.P., Building Saint Paul's, Thames and Hudson, London, 2007.

- CASEY, Christine, "De Architectura: An Irish Eighteenth-century Gloss," Architectural History, 1994, 37, pp. 80-95.

- COLVIN, Howard, "Letters and papers relating to the rebuilding of Combe Abbey, Warwickshire, 1681-1688," Walpole Society, 1984, 50, pp. 248-309.

- COLVIN, Howard and NEWMAN, John, Of Building; Roger North's Writings on Architecture, Oxford University Press, Oxford, 1981.

- CRAIG, Maurice "The Quest for Sir Edward Lovett Pearce," Irish Arts Review Yearbook, 1996, 12, pp. 27-34.

- D'AVILER, Charles Auguste, Cours d'Architecture, Jean Mariette, Paris, 1738; https://archive.org/details/ coursdarchitectuOOavil/page/6/mode/2up

- DOWNES, Kerry, Hawksmoor, A. Zwemmer, London, 1979.

- ESTERLY, David, The Lost Carving: A Journey to the Heart of Making, "Prelude," Duckworth Overlook, London, 2014.

- EVELYN, John, An Account of Architects and Architecture, London, 1706.

- FRIEDMAN, Terry, James Gibbs, Yale University Press, New Haven and London, 1984.

- GERBINO, Anthony and JOHNSTON, Stephen, Compass and Rule: Architecture as Mathematical Practice in England, 1500-1750, Yale University Press, New Haven and London, 2009.

- GIBBS, James, $A$ Book of Architecture Containing Designs of Buildings and Ornaments, London, 1728

- LAFFAN, William, and MULLIGAN, Kevin V., "Drawings for the Attic Statuary of the Casino at Marino,"Irish Architectural and Decorative Studies, 2013, xvi, pp. 145-60.

- GILLAM, S.G., The Building Accounts of the Radcliffe Camera, Oxford Historical Society, Oxford, 1958.

- GREEN, David, Grinling Gibbons: His Work as Carver and Statuary, Country Life, London, 1964.
- JOHNSTON, Stephen, “Making Mathematical Practice: Gentlemen, Practitioners and Artisans in Elizabethan England," $\mathrm{PhD}$ dissertation Cambridge University, 1994; http://www.mhs.ox.ac.uk/ staff/saj/thesis/

- MOBUS, Melody A.C., "The Burford Masons and the Changing World of Building Practice in England 1630-1730," PhD dissertation, The Open University, 2012; http://oro.open. ac.uk/54509/1/578641.pdf

- NAPOLI, John Nicholas, "The Art of the Appraisal: Measuring, Evaluating and Valuing Architecture in Early Modern Europe," Memoirs of the American Academy in Rome, 2009, LIV, pp. 201-44.

-PAYNE, Alina, "Materiality, Crafting and Scale in Renaissance Architecture," Oxford Art Journal, 2009, 32, 3, pp. 367-86.

- PYE, David, The Nature and Art of Workmanship, Cambridge University Press, Cambridge, 1968.

- ROBINSON, Henry W. and ADAMS, Walter, eds., The Diary of Robert Hooke M.A.. M.D., F.R.S. 1672-1680, Taylor \& Francis, London, 1935.

- ROWAN, Alistair, "The Building of Hopetoun," Architectural History, 1984, 27, pp. 183-209.

-SAINT, Andrew, "The conundrum of "by,"' edited by Malcolm Airs and William Whyte, Architectural History after Colvin: The Society of Architectural Historians of Great Britain Symposium 2011, Shaun Tyas, Donington, 2013, pp. 1-17.

- SEMPER, Gottfried, "Preliminary Remarks on Polychrome Architecture and Sculpture in Antiquity" (1834), in The Four Elements of Architecture and Other Writings, translated by Harry Francis Mallgrave and Wolfgang Hermann, Cambridge University Press, Cambridge and New York, 1989.

- WREN SOCIETY, The Fifth Volume of the Wren Society: Original Wren Drawings from All Souls, Hans Sloane, and Sir John Soane's Collections, Wren Society, Oxford, 1928.

RA. Revista de Arquitectura Núm. $23-2021$ P. 132-145 